\title{
Failure of infrastructure embankments induced by flooding and seepage: a neglected source of hazard
}

\author{
M. Polemio and P. Lollino \\ Italian National Research Council, Research Institute for Geo-Hydrological Protection, Bari, Italy \\ Received: 7 January 2011 - Revised: 7 November 2011 - Accepted: 26 November 2011 - Published: 22 December 2011
}

\begin{abstract}
The risk of failure of transportation embankments due to seepage induced by temporary and occasional impoundments taking place on the upstream side as a consequence of exceptional rainfalls is frequently underestimated. These failure events result from a combination of three main factors, i.e. the flooding event, the hydraulic weakness and the geotechnical weakness of the embankment. Based on the case study of a railway embankment in Southern Italy that collapsed in 2005 due to an upstream impoundment that occurred after few hours of a very intense rainfall, the paper describes a methodological approach aimed at assessing hazard of failure of transportation embankments induced by flooding and seepage. In particular, according to hydrological, hydraulic and geotechnical studies performed to define the factors affecting the process of the embankment failure, three subsequent activities are proposed: the historical analysis of flood damages at the watershed scale; and the assessment of the upstream peak impoundment based on hydrological analysis and the embankment stability analysis, these latter to be carried out at the site specific scale. The approach here proposed is planned to be further validated and improved by means of the application to other case studies, characterised by different contexts and embankment structures.
\end{abstract}

\section{Introduction}

Seepage due to upstream hydraulic head can sometimes represent the cause of general failure of embankments. In general, hazard associated to this process is well recognised for dam embankments and levees (El Shamy and Aydin, 2008; Serre et al., 2008), but is frequently underestimated for transportation embankments located in critical points, where a railway or a road intersects the drainage network. In particular, for transportation embankments risk associated to

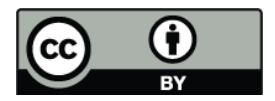

Correspondence to: P. Lollino (p.lollino@ba.irpi.cnr.it) seepage is related to temporary and occasional impoundment on the upstream side (JGS, 2006). Upstream impoundments can be generally produced by the combination of two different conditions. The first one can be defined as "flood event" and concerns the occurrence of either peak flood discharge in the drainage network or so-called secondary floods (stagnancy of rain on low permeability surfaces) as an effect of heavy rains (Petrucci and Polemio, 2009). Such events can be generally identified as flash floods, therefore local floods of high intensity and short duration, generally less than $6 \mathrm{~h}$; these floods can be extremely dangerous or dramatic, although being rare (Polemio, 2010). The second condition is represented by the "hydraulic weakness" of the transportation embankment, which is determined by drains, culverts, bridges, and, in general, hydraulic sections that can be easily obstructed during a flood or are underdesigned from a hydraulic point of view for the specific flood event. The occurrence of the latter condition is more frequent than what is generally expected. As such, this is frequently related to hydraulic design criteria defined on the basis of usual or nonexceptional floods, i.e. assessed by accounting for standard low return periods (20 or $50 \mathrm{yr}$ ) or considering low importance and/or short life of the infrastructure embankment. In both cases, the risk that the traffic can be interrupted for a short time as an effect of the water flow with frequency equal to the inverse of the selected flood return period is considered generally acceptable. Such an engineering approach is aimed at the cost optimisation of the transportation work (i.e. the increase of the design flood return period increases the incidence of the construction costs), but its reliability is frequently low, since the risk of failure of the embankment due to upstream water impoundment is generally not considered in the design procedures, probably because this kind of event is believed as exceptional, temporary and without relevant consequences on the embankment stability. In some other cases, a proper hydraulic design is neglected as the drainage catchment area seems to be small, the drainage network is not evident (as for the case of karstic areas) or floods are rare.

Published by Copernicus Publications on behalf of the European Geosciences Union. 
Where flood events along with hydraulic weakness are neglected, the embankment collapse can produce damages and casualties (e.g. Ansary and Safiullah, 2002; Tatsuoka et al., 2007; Ten Brinke et al., 2008; Polemio, 2010). This kind of hazard depends both on the probability of flooding events and on the embankment characteristics.

In general, seepage within embankments can generate two kinds of processes from a geotechnical point of view: sliding failures along the embankment slopes and internal erosion inside the embankment. Both the processes can induce, under particular conditions, the general failure of the embankment. In particular, sliding failure of the embankment slopes derives from the transient seepage process within the embankment and the development of pore water pressures, which are responsible for the reduction of the effective soil shear strength. On the other side, under specific seepage conditions, water flow can gradually induce internal erosion processes, which may occur under different modes such as (Fell and Fry, 2007; FEMA, 2006):

- backward erosion, if seepage exit gradient along the downstream area of the embankment is sufficiently high to mobilize soil particles and can evolve upstream if the hydraulic gradient remains high throughout the embankment (Terzaghi, 1939);

- suffusion, represented by the progressive migration of the fine grains through the coarser soil particles as an effect of seepage forces, this being generally possible if the soils forming the embankment are internally unstable. Internally unstable soils are usually broadly graded soils with particles from silt or clay to gravel size or gapgraded soils (Kenney and Lau, 1985 and 1986; Skempton and Brogan, 1994; Wan and Fell, 2008);

- concentrated leakage erosion, that can initiate through existing open cracks or interconnecting voids resulting from differential settlement, desiccation, hydraulic fracture or poorly compacted materials, when shear stress induced by concentrated flow exceeds the critical shear stress of the soil (Lane, 1934).

After initiation, all the processes above described can evolve across subsequent stages, up to the formation of a breach that corresponds to the embankment failure (Fell et al., 2003; Wan and Fell, 2008). In particular, a breach may occur according to several mechanisms, as:

- gross enlargement of erosion pipes,

- deep slope instability of the downstream slope,

- unravelling of the downstream slope face,

- overtopping, owing to crest settlement.

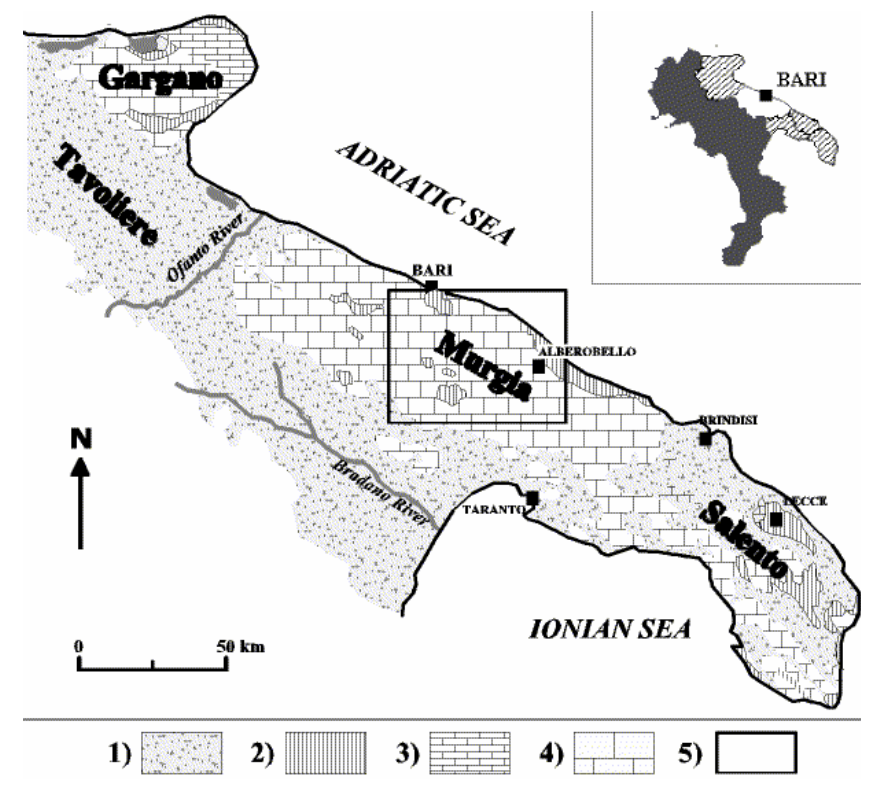

Fig. 1. Geological scheme of the Apulia Region. Upper rectangle: Southern Italy and provinces, white for Bari Province and lined for the rest of the Apulian provinces. Main rectangle: (1) recent clastic cover (PliocenePleistocene), (2) bioclastic carbonate rocks (Paleogene) and calcarenites (Miocene), (3) chert-carbonate rocks (Upper Jurassic-Cretaceous), (4) carbonate platform rocks (Upper JurassicCretaceous), (5) study area.

An area where this type of hazard was underestimated is located in Murgia, which is a karstic area in Puglia (southern Italy) characterised by Mediterranean weather conditions (Fig. 1). Here, rare flood events can trigger huge damages to the railway and road network. The last flood event occurred in 2005 and caused catastrophic damages, including six deaths, five of them being due to transportation embankment failure. Railways and roads were interrupted and severely damaged in several locations within an area of about $1500 \mathrm{~km}^{2}$ (Fig. 2). Therefore, in the present work this area has been chosen as representative study case in order to explore the factors that can produce such embankment failures (Gabriele et al., 2006; Mossa, 2007; Miglietta and Regano, 2008; Polemio, 2010). Based on the study performed on the specific test-area, this work is aimed at defining a methodological procedure to investigate the existence of hazard due to embankment failure induced by flooding. In particular, the approach is based on historical flood analysis, detailed hydrological analysis, embankment soil characterisation, finite element analysis of the seepage process, limit equilibrium calculations of the embankment slopes and assessment of the internal erosion likelihood. 


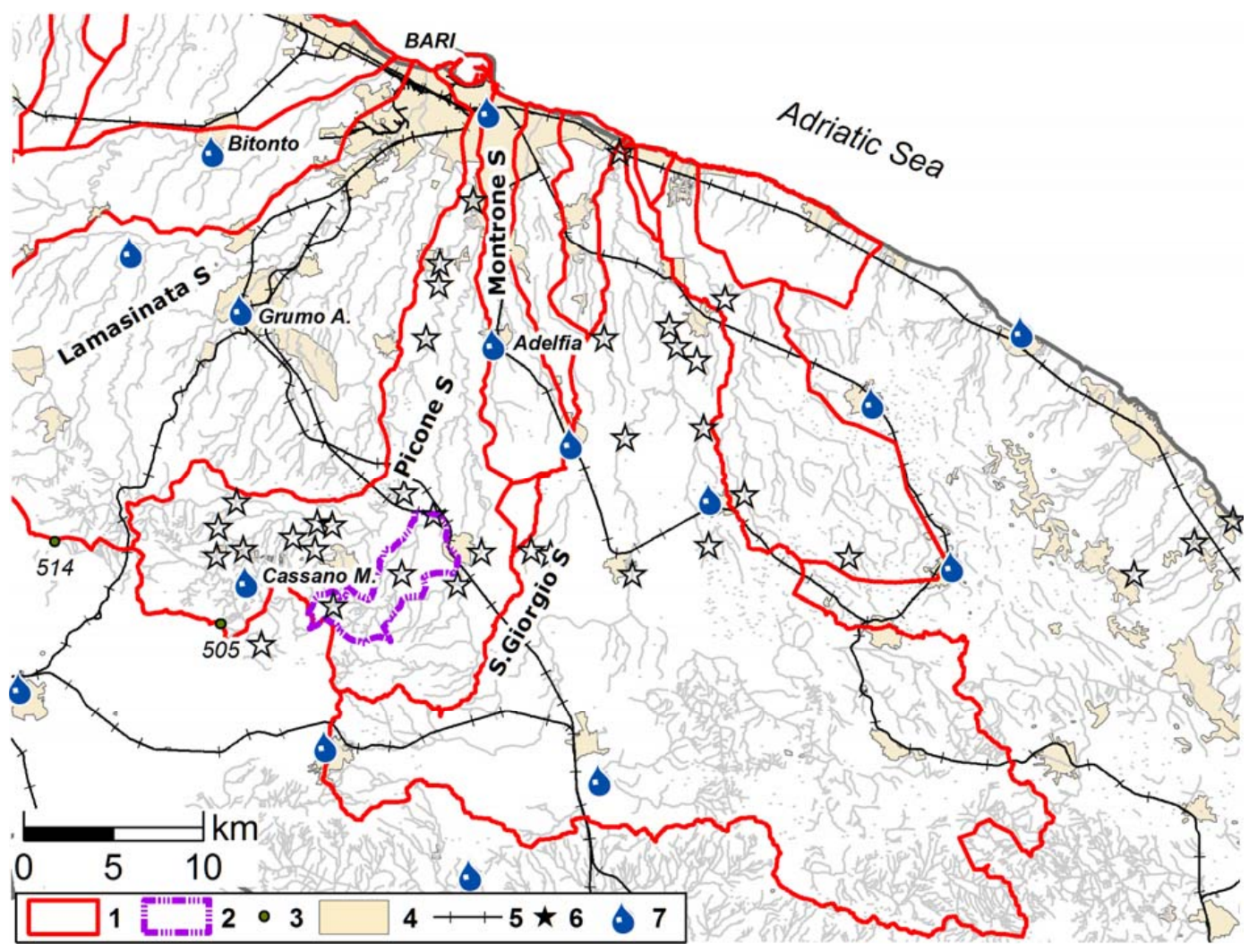

Fig. 2. Schematic map of streams, catchments, railways, roads, and damages. (1) main catchments (natural morphology, not considering artificial channels); (2) selected sub-catchment (Scappagrano Stream); (3) benchmark (m a.s.1.); (4) urbanised areas; (5) railways; (6) location of main damage of 2005 flood event, (7) rain gauges.

\section{Methodological approach}

Failure hazard assessment of embankments induced by flooding should concern the whole system of existing roads and railways, but can be more easily performed at the watershed scale. This kind of analysis, called "verification" hereinafter, can be developed according to three schematic subsequent stages or activities regarding a specific watershed. The three activities are: historical analysis of flood damages; assessment of peak impoundment; and embankment stability analysis. The first activity should be carried out considering the whole extent of the drainage basin, which generally includes many potential critical points; the remaining activities should instead be detailed for each of these critical points.

The historical analysis on flood damages is focused on the series of past or historical flood events which caused damages, with specific attention to transportation infrastructures (railways or roads) and particularly embankments. If the existence of past cases is verified, the analysis should highlight the recurrence period of damaging floods and discuss each specific event in order to check if embankment instability events due to upstream impoundment were observed in the past or could be identified for recently built infrastructures. This activity is based on the collection of flood data obtained from different information sources, such as newspapers, historical documents, maps, epigraphic markers on historic buildings, etchings, paintings, scientific articles, books, and statistical documentation available in the technical archives of public institutions (such as municipalities). The purpose is to improve the quality of data regarding flood characteristics (peak water levels, flooded areas, damage, etc.) and to expand the duration of the study period to assess flood recurrence period (Herget and Meurs, 2010; Llasat et al., 2006; Petrucci and Polemio, 2009; Polemio, 2010; Schmocker-Fackel and Naef, 2010). A small fraction of these documents describes the studied phenomenon in detail, but very often such documents deal with the effects, impact or damage (proxy-data) (Benito et al., 2004). Moreover, the information is not always completely reliable; in such cases, the data require a critical analysis of the sources (Glaser, 1996; Petrucci and Polemio, 2002 and 2009). Despite these difficulties, a historical analysis might give evidence of significant modifications produced by natural disasters or floods (Glaser and Stangl, 2004; Petrucci and Polemio, 2007). Therefore, this activity can represent a reliable tool in order to assess the existence and the level of hazard due the effects of flood events on railways and roads 
and, in such case, the specific contribution of the event to embankment damages can be considered. If some of these documents include quantitative data concerning rainfall, maximum flood head or stage, discharge yield and/or submerged area, they might be used for the numerical analysis typical of the second activity. The historical analysis can be then integrated using calculated flood maps, which are usually produced by drainage basin authorities or other local institutions, to complete the list of critical points and collect more hydrological information (Cook and Merwade, 2009).

At the end of the aforementioned activity, two schematic types of results can be hypothesized. The first one is the nonexistence of data concerning damages by floods or elements at risk, particularly in terms of transportation embankments. This is the case for areas at very low or negligible flood risk and/or areas in which transportation embankments were built considering all kind of effects due to floods. In this case, the activity can be stopped at this step by highlighting that the risk due to upstream impoundment of transportation embankments can reasonably be assessed as low or negligible.

If the existence of past damages to embankments is instead verified, the second activity of the methodology here proposed should be performed. This second activity regards the quantitative assessment of observed impoundments or peak floods at specific embankments, with the maximum level of accuracy allowed by the available data. Therefore, the peak impoundment assessment is aimed at defining the impoundment effects on the upstream side of embankments. Values of peak water head and impoundment duration should be determined on the basis of the historical research and/or flood maps based on geomorphological, hydrological or hydraulic flood studies, if existing. At this stage, the quantitative extension of historical analysis is pursued by using stream flow routing (the stream flow hydrograph in a stream section or along a whole stream), which denotes mathematical or numerical 1-D to 3-D formulations and techniques for flow simulation in natural rivers and channels (Cunge et al., 1980; Herget and Meurs, 2010; Ortega and Garzón, 2009; Polemio, 2010). The basic purpose of this analysis is to quantify the peak water head, the discharge yield and/or the submerged area by using one or two of these types of data as input to assess the more reliable missing information as output. With regard to this subject, many hydraulic or hydrologic methods are available in the literature and can be easily applied (ASCE, 1996). The study case hereafter described offers an example of such calculations based on procedures verified worldwide. Standardisation of this part of the activity is not straightforward, as it depends both on the type of available data and the method applied (Cook and Merwade, 2009). Selected historical data, treated by means of hydraulic and/or hydrological methods, may allow assessment of the water head variation on the upstream embankment face as a function of time; as an alternative, low-detail historical data can be used to assess the recurrence period of damaging floods.
The stream flow routing permits calculation of hydrographs in each stream section for floods of selected return period, this being assigned as not lower than the recurrence period of damaging historical floods.

The knowledge acquired at the end of this activity in terms of damaging floods characteristics can be applied to the whole studied drainage basin, assessing hydraulic critical conditions for each critical point and considering embankments that have been recently built upstream or downstream of embankments damaged in the past. At the same time, the results of the first two activities, i.e. historical analysis of flood damages and peak impoundment assessment, can be applied to embankments that have been built after the studied historical events.

For each of the critical situations detected in the drainage basin, the third activity of the methodology should be carried out. This is based on the geotechnical stability analysis of the embankment as subjected to the boundary and loading conditions imposed by the impoundment event, as reconstructed according to the previous activities. The geotechnical assessment includes:

1. stability analyses of the two embankment slopes by means of either limit equilibrium analyses or eventually more sophisticated numerical simulations;

2. analyses aimed at assessing the stability of the embankment soil material against the risk of internal erosion.

Regarding the latter, the susceptibility of the embankment to internal erosion according to all the main erosion processes above described, i.e. backward erosion, suffusion and concentrated leakage erosion, should be eventually assessed. In particular:

2a. for backward erosion, the corresponding susceptibility should be verified by means of a comparison between the exit hydraulic gradient and the critical value of gradient for piping (Terzaghi, 1939; Schmertmann, 2000);

2b. for concentrated leakage erosion, the analysis should consider the comparison between the shear stress induced by the flow through the potential leakage and the critical shear stress for erosion to occur (Lane, 1934);

2c. for suffusion, the corresponding susceptibility should be examined by means of geometric criteria aimed at defining if the soils are internally unstable (Kezdi, 1979; Kenney and Lau, 1985; Burenkova, 1993), whereas the conditions for the onset of suffusion should be defined by means of hydraulic criteria (Skempton and Brogan, 1994; Wan and Fell, 2008).

In general, the assessment of the embankment stability (third activity), which should be restricted only to the embankments that were found to be critical based on the watershedscale hydraulic analysis, should be based on the embankment geometry and soil physical and hydraulic property data, 


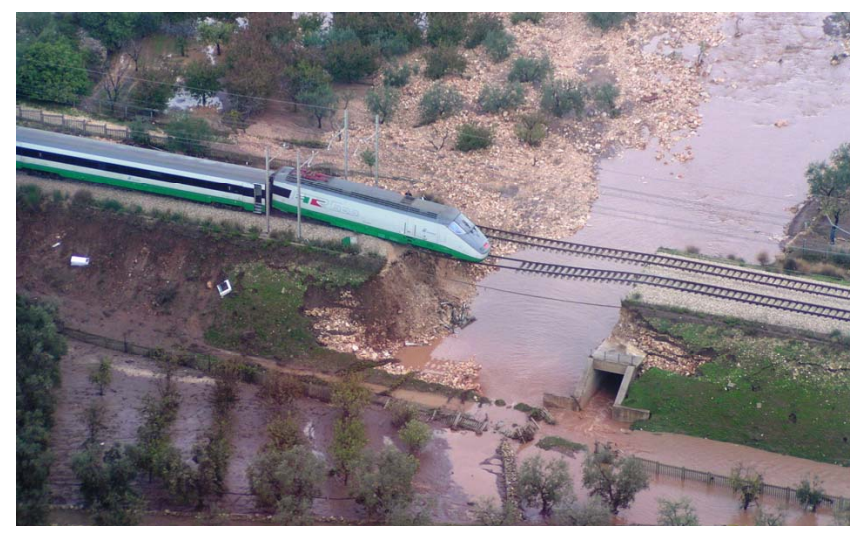

Fig. 3. View of the breach developed in the Acquaviva railway embankment (point 4 in Fig. 4) after 5 October 2005 flooding (picture taken from the upstream side).

which can be generally gained from the results of field and/or laboratory investigations performed at the time of design and construction of the embankment, available from the owner agency of the specific embankment. These data can be eventually augmented by specific in-situ and/or laboratory testing, the latter to be carried out on samples taken from boreholes or shallow trenches, which can be performed for the aim of the risk assessment.

\section{The study case}

The study case is located in Apulia, southern Italy, where the bedrock is largely karstic carbonate rocks. The region is dominated by three carbonate structural domains: Gargano, Salento, and Murgia (Cotecchia et al., 2005) (Fig. 1).

The altitude of Murgia, where the study area is located, varies from sea level to $680 \mathrm{~m}$ a.s.l. The karst environment consists of platform Cretaceous limestone and dolostone covered with thin layers of Plio-Quaternary rocks and soils. The carbonate rock is bedded, jointed and subject to karst phenomena (Cotecchia et al., 2005). The landscape is typically low-relief karst, characterised by dolines and flatbottom valleys (locally called lame) covered by thin alluvial deposits, mainly residual clayey deposits from karst processes. The climate is typically Mediterranean and semi-arid, where mean annual rainfall is 550 to $650 \mathrm{~mm}$ and mean annual temperature 14.3 to $16.8^{\circ} \mathrm{C}$.

During recent centuries, the Murgia was rarely hit by damaging flood events, but from the beginning of the twentiethcentury, flood events have been frequently observed in some basins surrounding Bari and other minor towns having mouths on the Adriatic Sea and the Ionian Sea coastlines (Polemio, 1998; Mossa, 2007; Polemio, 2010).

On 22 October 2005, a wide breach of the embankment of the national railway connecting Bari and Taranto occurred as a consequence of a flash flood (Fig. 3). The embankment collapsed after about $6 \mathrm{~h}$ from the beginning of the rainfall event, which produced a maximum upstream head of the impoundment of about $6.3 \mathrm{~m}$ from the ground level (the peak was defined based on to the debris observed close to the destroyed embankment; the head was determined by means of topographical measurements). After about 2 to $3 \mathrm{~h}$ the reservoir had reached the maximum level, the embankment failed with the dispersion of soil and rock blocks all over the downstream area. Evidences of shallow instability processes along both the two embankment slopes as well as of internal erosion processes were observed throughout the remaining portions of the embankment during field surveys performed by the authors after the failure event. A detailed back-analysis of this study case has been performed according to the methodology described in Sect. 2 in order to define the most likely causes of embankment failures and are described hereafter.

\subsection{Historical analysis of flood damages}

Regarding the examined watershed, historical and technical sources have been analysed in order to create a database of flood events covering a period as long as possible. The goal was to broaden the study period and gather more details about event recurrences (Polemio and Sdao, 1996; Petrucci and Polemio, 2002, 2009). In particular, data were gathered from several kinds of sources (Polemio, 2010): historical documents and archives, scientific papers and books on flood events, a public database for natural disasters, documentation available in the technical archives of public institutions, newspapers, direct observations of recent flood events, books, public statistical databases, historical archives and maps in public libraries and municipalities, which were collected in order to define the anthropogenic land modifications.

The research allowed the identification of 13 flood events from 1567 to 2007, each causing damages of different type and level; in particular, seven events caused damages to embankments (Table 1). It was noted that the landscape of the study area was modified many times by anthropogenic activities during the last millennia. The main anthropogenic modifications - deforestation, development of sheep grazing and cereal growing areas, changes in population and development of urban and rural areas - had effects on the flood recurrence period and the level of damages. The effects of these modifications were analysed to consider their impact in terms of damaging flood occurrences and hydrological characteristics. The construction of the first embankments took place in Italy at the end of the nineteenth-century due to the railway network development. From the beginning of the twentieth-century, damaging flood events have been frequently observed in Murgia. The 1926 flood, which is the first extremely catastrophic event recorded, caused many causalities and enormous damages, including damages to some embankments (Alfieri, 1927). The flood completely destroyed the bridge and the embankment at location $\mathrm{A}$ in 
Table 1. Flood events triggering damages to embankments with bridges and/or culverts.

\begin{tabular}{|c|c|c|c|c|c|}
\hline \multirow{2}{*}{ Year } & \multirow{2}{*}{ Stream } & \multicolumn{4}{|c|}{ Damages } \\
\hline & & Deaths & Injured & Others damages & Level \\
\hline 1567 & Picone (?) & & & & low \\
\hline 1833 & Picone & & & $?$ & low \\
\hline 1914 & Valenzano & & & Railway embankment & medium \\
\hline 1925 & Lamisanata & & & & medium \\
\hline 1926 & Picone, Valenzano & 20 & Tens & Town flooded, houses, factories, infrastructure railway & extremely high \\
\hline 1957 & Picone & & & Road culvert, narrow area & very low \\
\hline $2005^{*}$ & Picone, S.Giorgio & 6 & Tens & Town flooded, houses, roads, factories, railway, infrastructures & high \\
\hline
\end{tabular}

* The location of the main damages of the 2005 flood event are shown in Fig. 2.

Fig. 4, which were later rebuilt on the basis of an efficient hydraulic design, as confirmed by the 2005 flood that did not cause any damage to the new bridge. Based on a series of maximum flood head observations and applying simple stream flow routing procedures, the peak flow was calculated in a number of stream sections; in the area of location $\mathrm{A}$, the peak value was $225 \mathrm{~m}^{3} \mathrm{~s}^{-1}$, which is equal to a mean spatial contribution of $2.5 \mathrm{~m}^{3} \mathrm{~km}^{-2}$ of drainage basin (Alfieri, 1927). The 1957 flood caused very low damages, mainly the destruction of a paved road and a small road culvert (location B in Fig. 4), located upstream of the embankment hit in 2005 (location D in Fig. 4).

In 2005, the Picone Stream again produced disastrous flood events, as in 1926. The event of October 2005 caused six deaths, numerous injuries and many other types of damage (Table 1). The whole road network was heavily hit (Fig. 2); the flood event damaged bridges, culverts, embankments, walls and carriageways at 34 points. Many of these casualties and accidents were associated with new transportation works that were built in the previous $20 \mathrm{yr}$. Five people died in a car while crossing the drainage network in location C of Fig. 4, due to the rapid collapse of a culvert and of a road embankment. These works date to the 1990s and were intended to modernise a secondary road that forded the stream (generally dry due to the karstic nature of the area). Two remarks should be highlighted: the work design did not exploit the experience of the bridge collapse that occurred about $1 \mathrm{~km}$ downstream during the 1926 flood (location A in Fig. 4); no damage occurred in that critical point before the road "modernisation" (Polemio, 2010).

In location D of Fig. 4 (see also Fig. 3), where the embankment here examined is located, almost all of the injured people were passengers who miraculously survived a railway disaster: a train went off the rails at high velocity (over $120 \mathrm{~km} \mathrm{~h}^{-1}$ ) after crossing a $21 \mathrm{~m}$ long portion of the rails that was left unsupported due to the collapse of the underlying $7 \mathrm{~m}$ high embankment. The embankment and the corresponding culvert were constructed in the 1990s as part of a new double-track railway, which was built to replace the

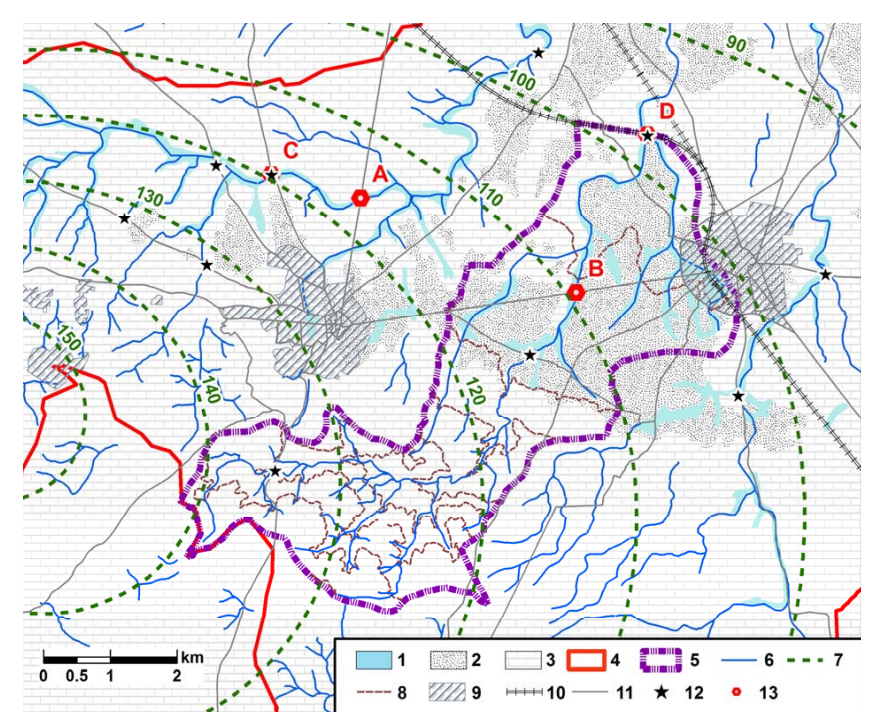

Fig. 4. Detailed map of selected sub-catchment: (1) alluvial deposits, clay and silty clay with pebbles; (2) calcarenite, secondly sand and conglomerate; (3) limestone and dolostone; (4) Picone Stream catchment divide; (5) selected sub-catchment (Scappagrano Stream); (6) drainage network; (7) Isohyet contours (mm) of total rainfall (from 02:30 LT on 22 October to 6:30 a.m. on 23 October); (8) isohypse (in the selected sub-basin); (9) urbanised areas; (10) railway; (11) road; (12) location of 2005 main damage; (13) location of relevant historical and recent damages.

old single-track railway and to provide a shorter and highspeed path. The old railway instead crosses the Scappagrano stream with a small bridge and a high embankment located about $700 \mathrm{~m}$ downstream from the new line.

Therefore, for the application here described, the upstream portion of the Picone stream was selected due to the high density and frequency of relevant flood events, and a subcatchment was specifically considered for the relevant effects of 2005 flood (Fig. 2). 


\subsection{Peak impoundment assessment}

In environments dominated by karstic features, the stream flow is very often so rare as to be considered exceptional when it is observed, regardless of the peak flow value (Ford and Williams, 2007). In these cases, research that involves the role of stream discharge must operate with a lack of time series on stream yield and, therefore, a hydro-geomorphological approach can be used. The hydrogeomorphological approach is mainly based on two types of data: rainfall and geomorphological characteristics of studied drainage basins.

In the specific case study, the hydro-geomorphological analysis considered rainfall data, qualitative hydrogeological characteristics of outcropping rocks and soils, and geomorphological data of the drainage basin within a GIS environment. Main sources of data were: topographical maps (1:50000 to 1:5000), geological map, soil map, land-use map, DTM (digital terrain model, $30 \mathrm{~m}$ spacing), aerial photos, authors' survey and rainfall data. All maps were used in digital formats; remaining data were processed to be analysed in a GIS environment. The Scappagrano stream, a small, upstream sub-basin of Picone Stream, which is closed by the upstream section of the selected embankment culvert (Figs. 2 and 4), was selected as our study area.

During the 2005 flood event, the flood flow was hindered by the small embankment culvert, thus giving rise to the upstream impoundment. At the culvert section the catchment surface is $23.0 \mathrm{~km}^{2}$ and the maximum stream length is $11.9 \mathrm{~km}$, whereas the altitude ranges from 272 (culvert bottom) to $475 \mathrm{~m}$ a.s.l. and the mean altitude is $356 \mathrm{~m}$ a.s.l. The concentration time, $t_{\mathrm{c}}$, i.e. the time of water flowing from the most remote point of the drainage basin to the outlet section, was assessed using methods suggested by Ferro (2006) and was determined to be roughly equal to $3 \mathrm{~h}$.

Rainfall data of the specific event from 17 rain gauges (managed by the Regional Civil Protection, Air Force and UCEA, the Italian Central Office of Agriculture Ecology) were available in terms of rainfall cumulative values every $0.5 \mathrm{~h}$. These gauges were located from 4 to $30 \mathrm{~km}$ from the selected sub-catchment (Fig. 2). Using the kriging method, $110 \times 10^{6} \mathrm{~m}^{3}$ of rain fell on a ground surface approximately equal to $1840 \mathrm{~km}^{2}$, from 02:30 local time (LT hereinafter) on 22 October to 06:30 LT on 23 October (Deutsch and Journel, 1992).

Long time series of the annual maximum rainfalls of short duration were used to assess the return period of the high intensity rainfall event that caused the 2005 flood (Polemio, 2010). Time series of the annual maximum of cumulative rainfall for 1, 3, 6, 12, and $24 \mathrm{~h}$ are available since 1929. The maximum rainfall return period was assessed by considering a confidence interval of 0.95 and a series of probability distribution function and methods for parameter assessment (Polemio and Sdao, 1996; ASCE, 1996; Polemio, 2010). The

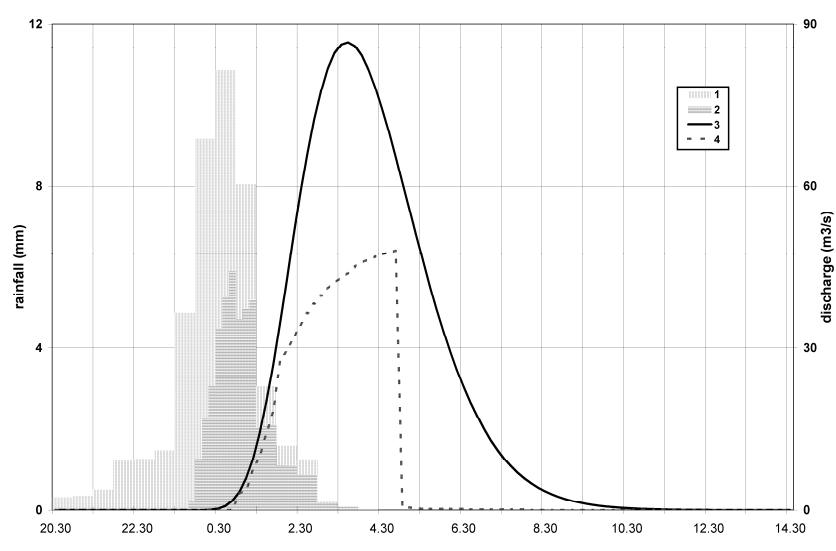

Fig. 5. Rainfall and flood of the 2005 event in the selected catchment. (1) Actual and (2) net rainfall (portion of rainfall available for runoff), (3) flood discharge at the catchment bottom, (4) culvert outflow.

return period of the maximum 3-h cumulative rainfall was estimated in the range $70-113 \mathrm{yr}$.

In the Scappagrano basin upstream of the selected embankment culvert, 97 to $140 \mathrm{~mm}(116 \mathrm{~mm}$ mean spatial value) and a total rain volume of $2.7 \times 10^{6} \mathrm{~m}^{3}$ fell, mostly over the time interval of $3 \mathrm{~h}$ (Fig. 4 ). The peak cumulative rainfall was observed at a gauge located $4 \mathrm{~km}$ westward of the basin, where $162 \mathrm{~mm}$ of rain fell. Plotting the 3-h cumulative rainfall with 0.5 -h steps, for each map the spatial mean rainfall was calculated for the selected catchment; the maximum was $\mathrm{H}=112.7 \mathrm{~mm}$, observed between 01:30 and 02:00 LT on 23 October. A rough assessment of the return period of $\mathrm{H}$ was in the range of $50-100 \mathrm{yr}$. The runoff in the study area was defined based on a direct transformation of the net rainfall excess with respect to the infiltration rate. The studied flood was generated by very high intensity 3 $\mathrm{h}$ rainfall. The observed rainfall defined the actual rainfall curve in Fig. 5.

The standard procedure of the Curve Number method $(\mathrm{CN})$ was used to assess the net rainfall of the catchment. CN was combined with the geomorphic instantaneous unit hydrograph method (GIUH), which permits the calculation of the hydrograph in the stream outlet section for which discharge measurements of the studied flood are unavailable (USDA, 1986). The output was compared with known data on the observed flood for calibration and validation of the model. Based on the rainfall observed before the flood event, the antecedent moisture conditions were classified as type II. The dimensionless $\mathrm{CN}$ parameter, defined in the range $0-100$, was estimated considering both soil infiltration characteristics and land use. The $\mathrm{CN}$ of the catchment was assessed by distinguishing two soil permeability classes: class A for soils with very high maximum infiltration rate, such as limestone and dolostone; and class B for soils with lower maximum infiltration rate, 


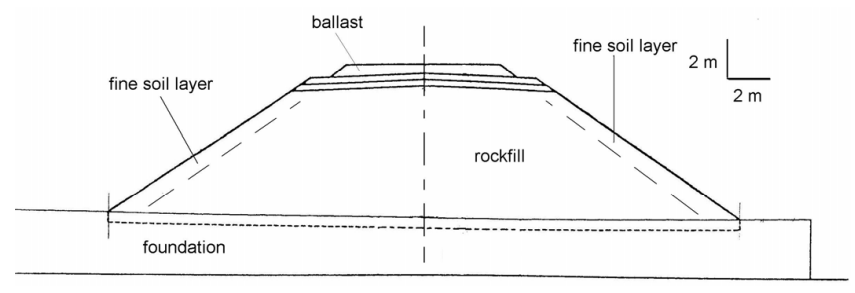

Fig. 6. Schematic cross-section of the Acquaviva embankment.

such as calcarenite (Fig. 4). The outcrops of alluvial deposits were included in the surrounding of limestone/dolostone or calcarenite. The land use was determined using up-to-date CORINE land-cover maps obtained from satellite data (EEA, 1994); the main classes were vineyard, complex cultivation patterns (due to greenhouses for example), wood, olive grove and grazing, in decreasing order. The spatial mean value of $\mathrm{CN}$ was 67 for the catchment. Assessing net rainfall, a time step of $10^{\prime}$ (instead of $30^{\prime}$ of available rainfall data) was used by linearizing the $\mathrm{CN}$ method output to refine the GIUH method application (Fig. 5). The GIUH method accounts for the influence of the channel network on the delay and the shape of the hydrograph (Nash, 1957; Rodriguez-Iturbe and Valdes, 1979; USDA, 1986). The core of the method is to define the instantaneous unit hydrograph (IUH) on the basis of geomorphological classification criterion of the drainage network, the so-called Horton-Strahler criterion (Horton, 1945; Strahler, 1952). Using this method, we calculated the flood discharge hydrograph of Fig. 5.

Validating the flood hydrograph and reducing the uncertainty could be useful for flood discharge assessment since stream flow measurements were unavailable for the study area. This limitation was solved by taking advantage of the 2005 event. In this case, a small concrete culvert (Fig. 3, hydraulic section of $9 \mathrm{~m}^{2}$ ) could not accommodate the outflow of peak discharge, creating a large flooded area and an area of water storage on the upstream side of the embankment. Seepage across the embankment caused the rapid collapse of a 21-m long portion of the structure, where the maximum impounded water head was reached, causing a very quick emptying of the flooded area. The maximum water head and the relationship between water altitude and water volume (190000 $\mathrm{m}^{3}$ peak value) were defined in detail with specific in-situ topographic measurements, while the temporal sequence of water stages was defined based on official information from the railway authorities. The discharge outflow of the culvert was assessed with well-known formulas that consider the culvert geometry and the upstream water head (peak value $48 \mathrm{~m}^{3} \mathrm{~s}^{-1}$ ). The results in Fig. 5 are consistent with all measurements and information collected due to the railway disaster, thus confirming the accuracy of the applied method. The upstream flood peak flow was $87 \mathrm{~m}^{3} \mathrm{~s}^{-1}$, which occurred at about 03:40 LT on 23 October, about $4 \mathrm{~h}$ after the high intensity rain began. The total volume of the flood was equal to $1.1 \times 10^{6} \mathrm{~m}^{3}$.

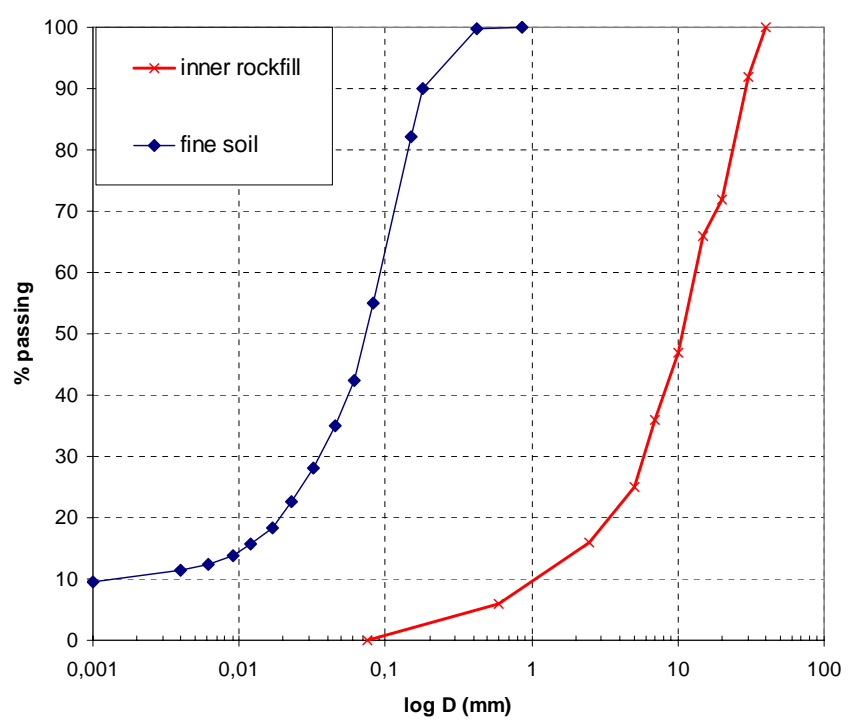

Fig. 7. Grain size distribution curves of the inner rockfill and finer soil along the slopes for the Acquaviva railway embankment.

\subsection{Assessment of the embankment stability}

A schematic cross-section of the embankment under study in the centre of the valley is shown in Fig. 6. The inner portion of the embankment was formed of a widely graded rockfill that was confined by two layers of finer soils, with variable thickness between 80 and $150 \mathrm{~cm}$, along the embankment slopes. The grain size distribution curves of the rockfill, as defined in accordance with the measurements carried out during the construction of the embankment by the Italian Railway Agency, are shown in Fig. 7. The curves indicate that the inner rockfill was composed of coarse gravel (25\%), medium gravel (45\%), fine gravel $(15 \%)$ and sands $(15 \%)$; the sand component was formed of $6 \%$ of fine and medium sands and $9 \%$ of coarse sand. Unfortunately, direct measurements on the grain size curve of the finer soil along the slopes are not available, although this soil can be classified to be in the range between silt and sand. Therefore, in the analysis described later on, a representative grain size curve typical for this class of soil has been assumed (Fig. 7).

\subsubsection{Seepage analysis}

A finite element analysis of the transient seepage process within the embankment, taking into account unsaturated conditions of the soil, has been carried out in order to investigate the variation with time of the flow regime as an effect of the provisional impoundment on the upstream side. The results have been then used both to evaluate the hydraulic conditions capable of producing the onset of the piping process and to back-calculate the sliding processes observed along the embankment slopes. The mesh adopted for the calculation is reported in Fig. 8. A boundary condition variable 


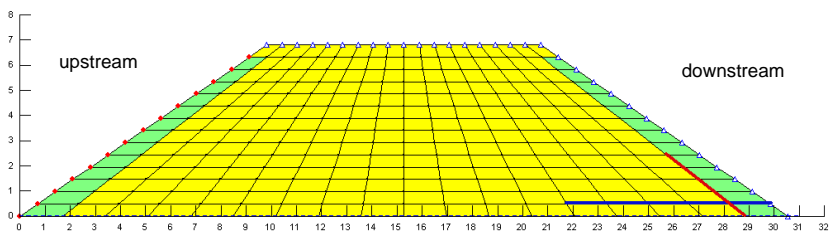

Fig. 8. Mesh and boundary conditions adopted for the seepage analysis. Green elements indicate low-permeability soil strata along the slopes; yellow elements represent rockfill. Red circles indicate nodes with a prescribed hydraulic head; blue empty triangles indicate free draining nodes. The inclined red line in the downstream toe area indicates the line of numerical monitoring of the pore pressure (see Fig. 12); the horizontal blue line in the downstream toe area represents the line of numerical monitoring of the hydraulic gradient (see Fig. 13).

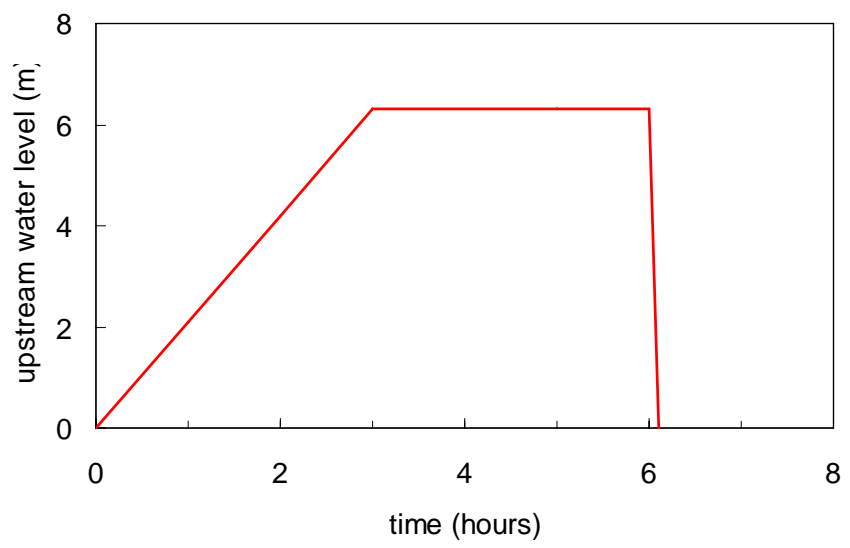

Fig. 9. Hydraulic head condition variable with time applied in the seepage analysis to the upstream slope boundary.

with time in accordance with the impoundment level data reported in Sect. 3.2 has been imposed on the upstream face (Fig. 9). A free-draining boundary condition has been prescribed along the downstream face, whereas an impermeable boundary condition has been imposed along the bottom of the embankment. A saturation line at the bottom of the embankment has been assumed as initial condition $(t=0)$. Both of the materials of the embankment have been assumed to have isotropic hydraulic properties. Since no field test could be performed on the material as placed in-situ, the value of the coefficient of permeability of the saturated soil forming the inner rockfill within the embankment has been derived from the corresponding grain-size distribution. According to Chapuis and Aubertin (2003), this method can be used for a quick but quite confident estimate of the $k$ value, although it can be affected by limitations especially for the investigation of eventual anisotropic properties. The value of the saturated coefficient of permeability for the inner rockfill was estimated to be $K_{1}=5 \times 10^{-3} \mathrm{~m} \mathrm{~s}^{-1}$, whereas for the fine soil along the slopes was equal to $K_{2}=4 \times 10^{-7} \mathrm{~m} \mathrm{~s}^{-1}$. Based

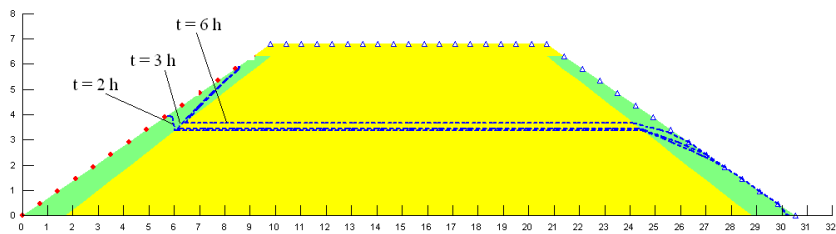

Fig. 10. Saturation level in the embankment at different times in the hypothesis of low permeability soil strata along the two embankment slopes.

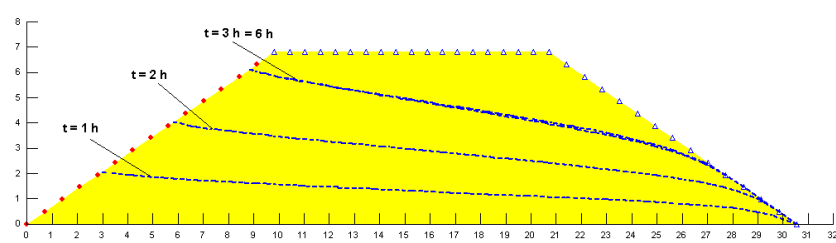

Fig. 11. Saturation level in the embankment at different times in the hypothesis of homogeneous embankment.

on the corresponding grain size distributions, the soil-water characteristic curve of the rockfill has been derived by means of the Van Genuchten (1980) relationship, whereas the soilwater characteristic curve of the fine soil has been assumed based on the Arya and Paris relationship (1981), which is generally considered as more suitable for sandy soils; the laws of variation of the coefficient of permeability with suction have instead been defined by means of the Green and Corey approach (1971).

The results of the seepage analysis show that the saturation line reaches the maximum level, which in the rockfill remains about horizontal, $3 \mathrm{~m}$ above the base of the embankment, during the raising of the impoundment level (Fig. 10). The geometry of the saturation line within the upstream fine soil stratum is directly related to the variation of the upstream boundary condition. Figure 10 also shows that the evolution with time of the saturation line is significantly affected by the difference of permeability of the two soils. In particular, the influence of the fine soil strata along the embankment slopes is highlighted if such seepage domain is compared with that deriving from a similar analysis simulating homogeneous embankment conditions, as shown in Fig. 11. Different pore pressure distributions within the embankment result from these two flow processes. In particular, the values of the pore pressures calculated along the red line indicated in Fig. 8 for the case of homogeneous embankment and those predicted for embankment with two fine soil strata at time $t=6 \mathrm{~h}$ (i.e. after $3 \mathrm{~h}$ of constant maximum reservoir level) are compared in Fig. 12. The figure shows that for the case of fine soil slopes, values of pore pressures higher than for the homogeneous case develop at embankment heights lower than $3 \mathrm{~m}$. 


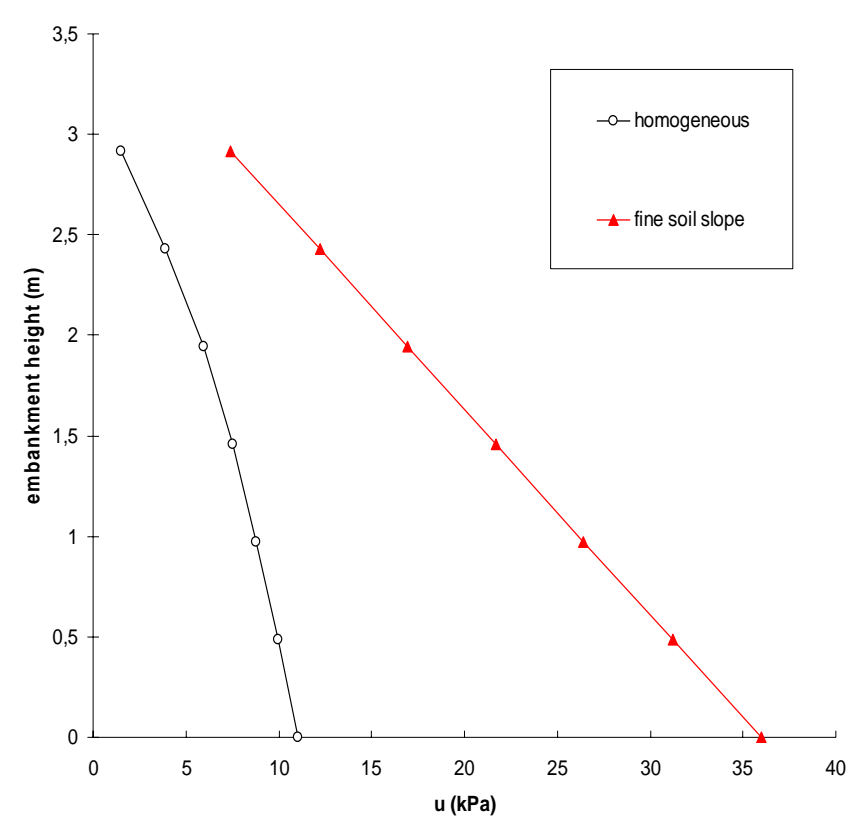

Fig. 12. Pore water pressures calculated at the downstream toe area (see red line in Fig. 8) at time $t=6 \mathrm{~h}$ (see Fig. 9) for different embankment configurations.

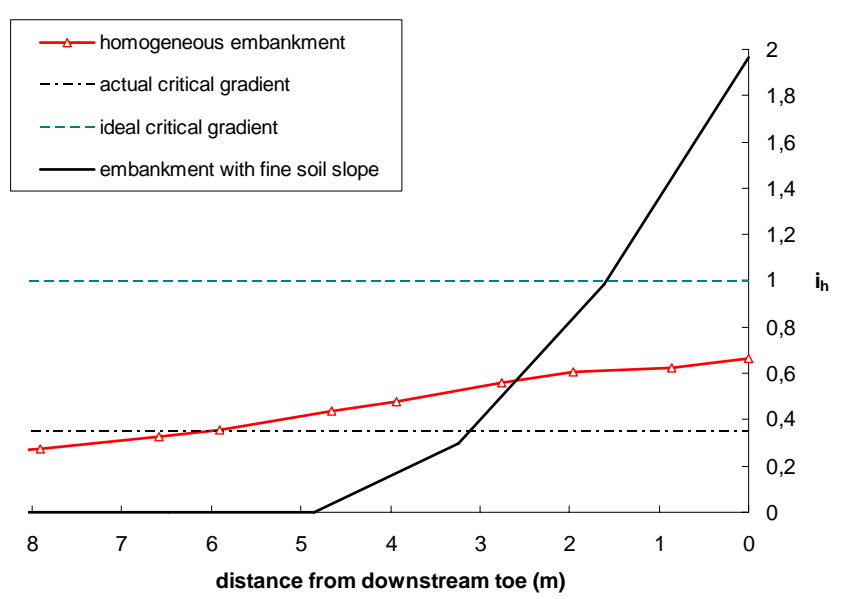

Fig. 13. Outflow horizontal gradient calculated at the downstream toe (see blue line in Fig. 8) at time $t=6 \mathrm{~h}$ (see Fig. 9) for different embankment configurations and comparison with gradient values critical for the onset of piping.

The values of the horizontal hydraulic gradient at the nodes along the blue line in Fig. 8 have also been calculated at $t=6 \mathrm{~h}$ and compared for the two configurations of the embankment in Fig. 13. The hydraulic gradient for the homogeneous rockfill embankment reaches the maximum value at the downstream face $\left(i_{\mathrm{h}}=0.65\right)$ and then reduces gradually to values less than $i_{\mathrm{h}}=0.3$ in the very inner portion of the embankment. For the case of a rockfill embankment with low-permeability soil along the embankment faces, the gradient reaches the highest values within the fine soil layer $\left(i_{\mathrm{h}}=1.2\right.$ to 1.9$)$, then reduces in the adjacent rockfill area to lower but still significant values $\left(i_{\mathrm{h}}=0.4\right.$ to 1.2$)$ and finally becomes negligible in the innermost areas.

\subsubsection{Analysis of the failure process of the embankment}

\section{Slope stability}

Several shallow sliding or unravelling processes, mainly involving the fine soil strata along the embankment slopes, were observed along the remaining portion of the embankment during field surveys performed after the failure event (Fig. 14). Based on the pore pressure distributions calculated by means of the transient seepage analysis, limit equilibrium back-analyses have been carried out using the MorgesternPrice method (Morgenstern and Price, 1965) with respect to sliding surfaces along the embankment slopes that resemble those observed in the field (Fig. 15a and b). In particular, the strength parameters of the rockfill have been assigned to be equal to $c^{\prime}=0 \mathrm{kPa}$ and $\varphi^{\prime}=36^{\circ}$, since these parameters can be assumed as representative of a lower boundary of the shear strength of the examined rockfill material, whereas the mobilised strength parameters of the fine soil strata along the embankment slopes have been derived as output of the analysis.

Assuming the pore pressure distribution at time $t=6 \mathrm{~h}$ from the beginning of the raising of the impoundment level and two values of the mobilised cohesion of the fine soil respectively equal to 0 and $5 \mathrm{kPa}$, the results of the backanalysis for the sliding surface along the downstream slope in Fig. 15a indicate values of the mobilised friction angle of the fine soil that are equal to:

$c_{\mathrm{m}}^{\prime}=0: \quad \varphi_{\mathrm{m}}^{\prime}=36^{\circ}$

$c_{\mathrm{m}}^{\prime}=5 \mathrm{kPa}: \quad \varphi_{\mathrm{m}}^{\prime}=25^{\circ}$

whereas higher values of the mobilised friction angle have been obtained for the sliding surface along the upstream slope indicated in Fig. 15b, e.g.:

$c_{\mathrm{m}}^{\prime}=0: \quad \varphi_{\mathrm{m}}^{\prime}=42^{\circ}$

$c_{\mathrm{m}}^{\prime}=5 \mathrm{kPa}: \quad \varphi_{\mathrm{m}}^{\prime}=38^{\circ}$

These quite high mobilised strength values should confirm that shallow slope instability processes were likely to have occurred along both downstream and upstream slope of the embankment due to the very unfavourable flow conditions that took place in the embankment during the flooding event. Moreover, flow sliding might also have occurred since the soils involved are in the range of soils potentially susceptible to liquefaction and flow sliding according to their particle size distributions, as indicated by Hunter and Fell (2003). Unravelling was also likely to occur along the downstream slope due to very high seepage flow existing at the downstream toe. 

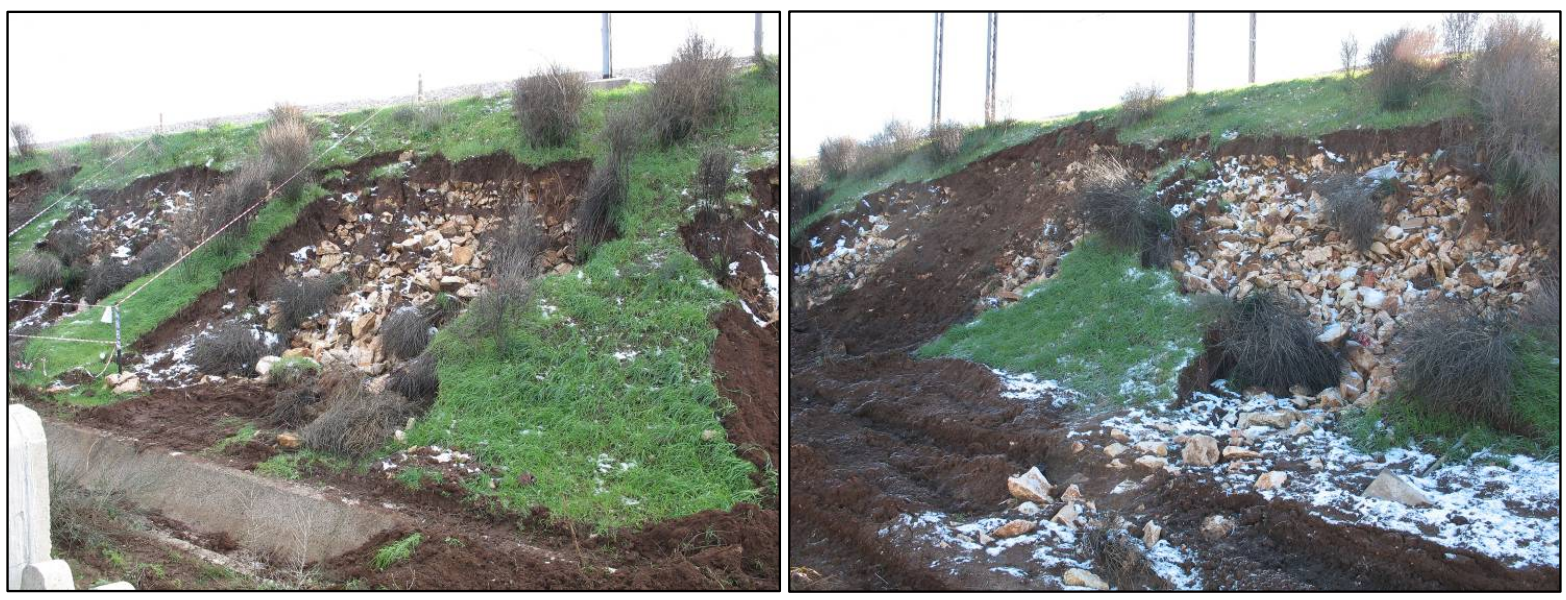

Fig. 14. Unravelling/sliding failures observed along the slopes of the remaining portion of the Acquaviva embankment.
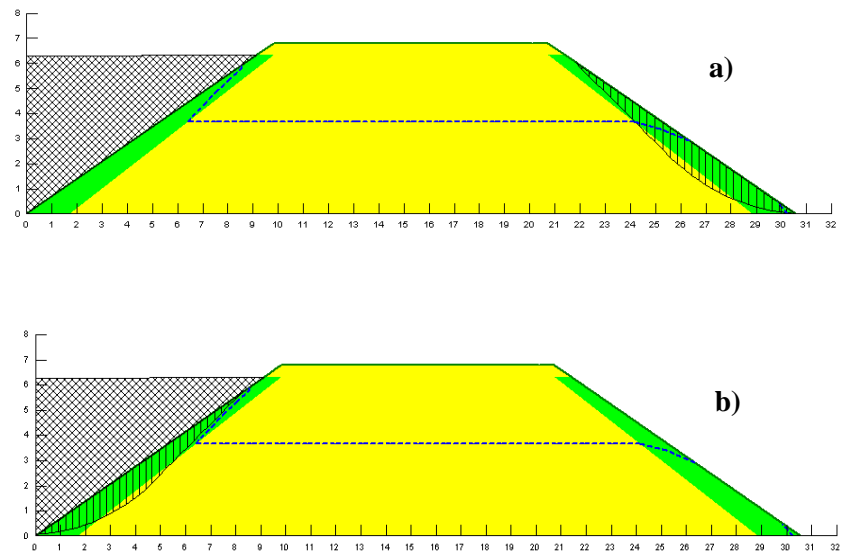

Fig. 15. Back-analysis of the slope stability of the embankment at time $t=6 \mathrm{~h}$. Sliding surface assumed along the downstream slope (a) and along the upstream slope (b). The blue dashed line represents the saturation level calculated at the same time.

\section{Internal erosion}

Quantitative assessments aimed at verifying the likelihood of occurrence of the different processes of internal erosion have been carried out for the specific examined embankment.

The procedure for the assessment of the susceptibility to suffusion has been based on the evaluation of the shape curve H-F, as described by Kenney and Lau (1985, 1986), which is to verify if such curve lies for some portion under the critical lines provided by the same authors. Thereafter, the value of the hydraulic gradient as determined from the finite element seepage analysis (see Sect. 3.3.1.) has been compared with the value of the critical hydraulic gradient calculated according to Skempton and Brogan (1994). Based on the grain size distribution curve defined for the inner rockfill, the corresponding "shape curve" in the H-F plot has been

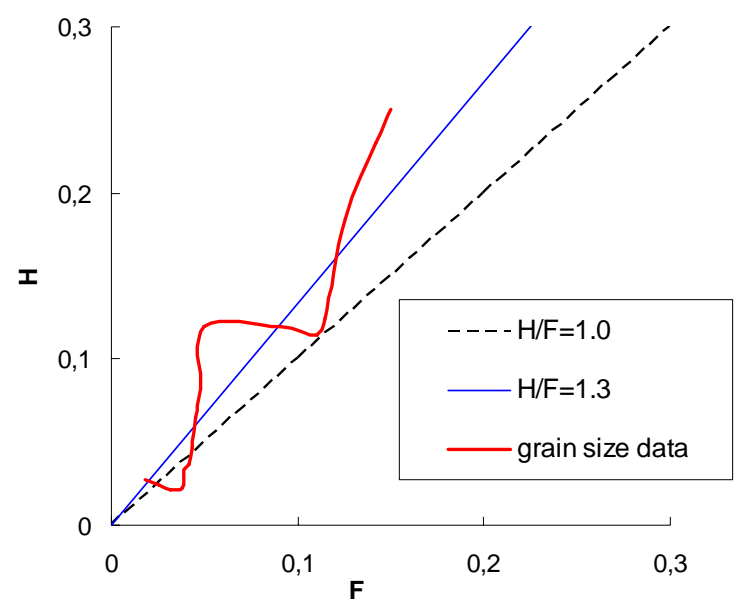

Fig. 16. H/F shape curve calculated for the rockfill grain size curve in Fig. 7 and comparison with critical H/F curves.

derived (Fig. 16). The curve has been defined for $F$ values between 0 and 0.2 , since the material is characterised by a uniformity coefficient $C_{\mathrm{u}}$ higher than 3 (see Kenney and Lau, 1985). Figure 16 shows that the curve representative of the embankment rockfill is typical of a material highly unstable for two ranges of diameters: in fact, a minimum value of the ratio $\mathrm{H} / \mathrm{F}=0.57$ is obtained for a diameter $D$ in the range $[0.1,0.3]$ and also a relative minimum $\mathrm{H} / \mathrm{F}=1.0$ corresponds to the range of $D=[1,1.5]$. These values of the stability index clearly confirm the susceptibility of the material to be internally unstable according to the criterion provided by Kenney and Lau (1985). Moreover, the material also is shown to be unstable according to the Kezdi criterion (1979), since the value of the ratio $d_{85}^{\prime} / D_{15}^{\prime}$ is higher than 4. The corresponding value of the critical gradient has been then estimated based on the experimental works of Skempton and Brogan (1994). In particular, considering a range of 


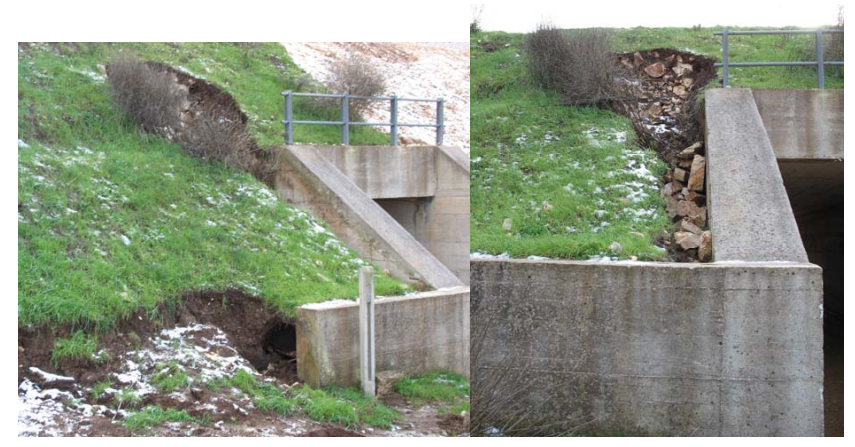

Fig. 17. Photos of the concentrated erosion pipe at the contact between the wall of the concrete conduit and the soil material.

$\mathrm{H} / \mathrm{F}$ values equal to 0.6 to 1.0 , the mean value of the actual critical gradient of such unstable material is approximately equal to:

$i_{\text {cr }}=0.25 \div 0.3 \times i_{\mathrm{c}}=0.35$

where $i_{\mathrm{c}}$ represents the critical gradient deduced from the Terzaghi theory $\left(i_{\mathrm{c}}=1.15\right)$.

It turns out that, for the outer portion of the embankment, the hydraulic gradient calculated in the case of fine soil along the embankment slope is significantly higher than critical gradient for unstable material and is also higher than that for stable material, but it reduces down to negligible values in the inner areas of the embankment (Fig. 13). However, the value of the hydraulic gradient calculated under conditions of homogeneous embankment, which were presumably established after shallow instability processes and unravelling took place both upstream and downstream, is of the same order of magnitude as the critical gradient in the inner areas of the embankment. These results should explain that suffusion was very likely to have occurred within the embankment during the flooding event. Therefore, this process can represent a possible cause for a settlement of the embankment in the failed portion, with the consequent overtopping and the global failure of the embankment.

The comparison of the calculated values of the hydraulic gradient with the critical gradient for piping, as defined according to the Terzaghi theory, instead makes backward erosion more unlikely than suffusion. Evidence presumed to indicate concentrated erosion holes at the contact between the concrete conduit and the nearby rockfill areas, the latter being generally exposed to the risk of poor compaction and high permeability, was also observed during field surveys after the failure event. In Fig. 17 two pictures of the effects of an erosion pipe within the soil material close to a wall of the conduit are shown. In order to perform a preliminary evaluation of the likelihood of initiation and propagation of concentrated erosion in a hole of the same size, an assessment of the hydraulic shear stress in a cylindrical pipe as a function of the pipe length, assuming a mean pipe diameter of $D=0.5 \mathrm{~m}$ and a mean water head loss due to friction

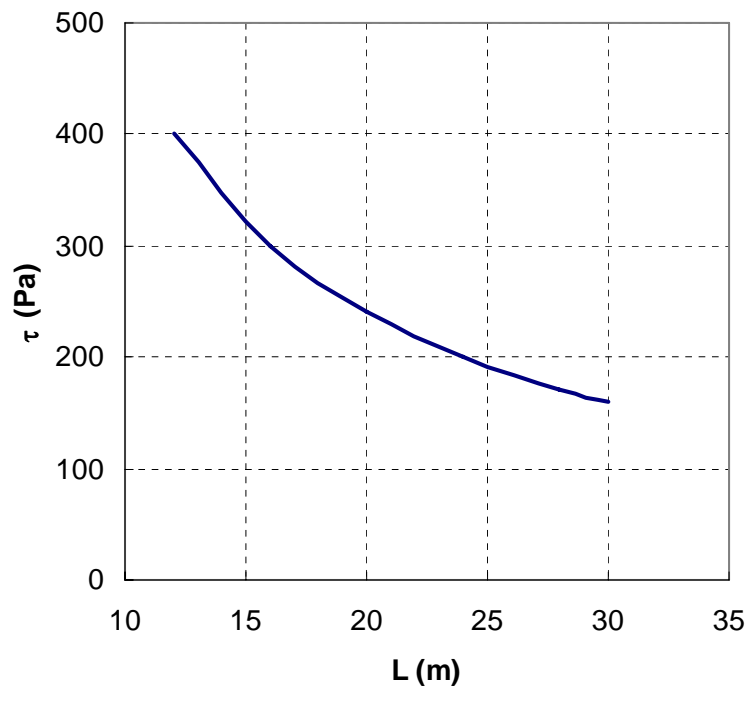

Fig. 18. Estimated hydraulic shear stress in a cylindrical pipe as a function of the pipe length (pipe diameter of $D=0.5 \mathrm{~m}$; water head loss of $\mathrm{H}_{\mathrm{f}}=4 \mathrm{~m}$ )

of $\mathrm{H}_{\mathrm{f}}=4 \mathrm{~m}$, has been carried out. The results are shown in Fig. 18 and indicate values of the shear stress that are higher than the critical shear stress provided for coarse grained soils by Wan and Fell (2004).

\section{Discussion}

The methodology here described represents an example of a preliminary analysis aimed at evaluating the hazard existing for embankments located in specific areas where transient upstream reservoirs due to intense flooding can develop, with the consequent risk of internal erosion and catastrophic failure of the same structures. The hydraulic analysis aimed at evaluating the history of the upstream boundary condition induced by flooding as well as the methodology adopted to determine the internal erosion susceptibility or the instability processes along the embankment slopes have been presented in the previous sections with respect to the specific case study. The methodology proposed can be used to assess a scale of hazard among the embankments existing within a watershed. As such, the hydraulic analysis should be aimed at defining the hydrograph for those sections in the whole watershed under study that are shown to be at risk; and, in particular, the return period of specific extreme rainfall events and the peak impoundment induced at the considered sections should be determined. For those embankments that are determined to be critical according to the hydraulic analysis, the internal geometry of the embankment and the corresponding soil physical and hydraulic properties should be assessed either by means of the information available from the design of the embankment or by means of appropriate field 
or laboratory testing, the latter to be carried out on samples taken from boreholes or shallow trenches. Then, the geotechnical analysis aimed at assessing both the susceptibility to internal erosion of the embankment and the slope stability conditions should be performed. It follows that the embankments that are determined to be characterised by a high level of failure hazard should be identified and proper strategies of remediation should eventually be considered accordingly.

The main limitations of the methodology proposed regard the rather high level of uncertainty related to the difficulty in defining accurate soil properties of the embankment as well as the most likely modes of failure. Therefore, since the physical processes involved in the failure of an embankment are often complex and not precisely quantifiable, such an approach can act as a guide to the likely behaviour of the embankment under extreme flooding conditions.

\section{Concluding remarks}

The paper proposes a methodology to approach the problem of assessing hazard associated with failure of existing transportation embankments due to flooding. The methodology is based on a historical analysis of flood damages at the watershed scale, a peak impoundment analysis at the single embankment scale and a consequent analysis of the embankment stability.

In this paper, a specific back-analysis of the collapse of a national railway embankment induced by a flash flood event has been carried out as an example of the possible methodological approach.

The results of the analysis indicate that the failure of the railway embankment is thought to be induced by internal erosion processes, probably consisting of suffusion of the soil forming the embankment, together with concentrated pipe erosion along the contact between the rockfill and the concrete culvert, that led within a few hours to the global failure of a large portion of the structure.

Seepage and limit equilibrium analyses have also shown that the shallow slope failures observed along both the downstream and upstream slopes were induced by high pore water pressures induced by the transient flow process within the embankment. However, these shallow slope failures are thought to be not the primary cause of the embankment failure, but rather they likely enhanced the internal erosion processes.

Edited by: D. Keefer

Reviewed by: two anonymous referees

\section{References}

Alfieri, S.: L'alluvione della zona barese nel Novembre 1926, Annali del Ministero dei Lavori Pubblici, Italy, 65, 193-223, 1927.

Ansary, M. A. and Safiullah A. M. M.: Effect of flood on earth structures: a case study, in: Engineering Concerns of Flood, edited by: Ali, M. A., Seraj, S. M., and Ahmad, S., 101-113, 2002.

Arya, L. M. and Paris, J. F.: A physicoempirical model to predict soil moisture characteristics from particle-size distribution and bulk density data, Soil Sci. Soc. Am. J., 45, 1023-1030, 1981.

ASCE - Hydrology Handbook: American Society Of Civil Engineers, Manual and Reports on Engineering Practice, 28, 784 pp., 1996.

Benito, G., Lang, M., Barriendos, M., Llasat, M. C., Francés, F., Ouarda, T., Thorndycraft, V. R., Enzel, Y., Bardossy, A., Coeur, D., and Bobée, B.: Use of Systematic, Palaeoflood and Historical Data for the Improvement of Flood Risk Estimation, Review of Scientific Methods, Nat. Hazards., 31, 623-643, 2004.

Burenkova, V. V.: Assessment of suffosion in non-cohesive and graded soils, in: Filters in geotechnical and hydraulic engineering, edited by: Browns, J., Heibaum, M., and Schuler, U., Balkema, Rotterdam, 357-360, 1993.

Chapuis, R. P. and Aubertin, M.: On the use of the KozenyCarman equation to predict the hydraulic conductivity of soils, Can. Geotech. J., 40, 616-628, 2003.

Cook, A. and Merwade, V.: Effect of topographic data, geometric configuration and modeling approach on flood inundation mapping, J. Hydrol., 377, 131-142, 2009.

Cotecchia, V., Grassi, D. and Polemio, M.: Carbonate aquifers in Apulia and seawater intrusion, Giornale di Geologia Applicata, 1, 219-231, 2005.

Cunge, J. A., Holly, F. M. and Verwey, A.: Practical aspects of computational river hydraulics, Pitman Publishing Ltd., London, 420 pp., 1980.

Deutsch, C. V. and Journel, A. G.: Geostatistical software library and user's guide, Oxford University Press, New York, 335 pp. 1992.

EEA - European Environment Agency: CORINE Land Cover, available at: http://www.eea.europa.eu/publications/ COR0-landcover (last access: 28 February 2011), 1994.

El Shamy, U. and Aydin, F.: Multiscale modeling of flood-induced piping in river levees, J. Geotech. Geoenviron. Eng., ASCE, 134, 1385-1398, 2008.

FEMA - Federal Emergency Management Agency: Conduits through embankment dams, 2006.

Fell, R. and Fry, J. J.: The state of the art of assessing the likelihood of internal erosion of embankment dams, water retaining structures and their foundations, in: Internal erosion of dams and their foundations, edited by: Fell, R. and Fry, J. J., Taylor and Francis, London, 1-24, 2007.

Fell, R., Wan., C. F., Cyganiewick, J., and Foster, M.: Time for development of internal erosion and piping in embankment dams, J. Geotech. Geoenviron. Eng., ASCE, 129, 307-314, 2003.

Ferro, V.: La sistemazione dei bacini idrografici, McGraw-Hill, 848 pp., 2006.

Ford, D. and Williams, P.: Karst hydrogeology and geomorphology, J. Wiley Ed., England, 562 pp., 2007.

Gabriele, S., Chiaravallotti, F., and Cotecchia, V.: The pluviometric event of 22 October 2005 in Apulia, L'acqua, 5, 37-48, 2006.

Glaser, R.: Data and methods of climatological evaluation in histor- 
ical climatology, Hist. Soc. Res., 21, 56-88, 1996.

Glaser, R. and Stangl, H.: Climate and floods in central Europe since ad 1000: data, methods, results and consequences, Surv. Geophys., 25, 485-510, 2004.

Green, R. E. and Corey, J. C.: Calculation of hydraulic conductivity: a further evaluation of some predictive methods, Soil Sci. Soc. Am. Proc., 35, 3-8, 1971.

Herget, J. and Meurs, H.: Reconstructing peak discharges for historic flood levels in the city of Cologne, Germany, Glob. Planet. Change, 70, 108-116, 2010.

Horton, R. E.: Erosional development of streams and their drainage basins: hydrophysical approach to quantitative morphology, Bull. Geol. Soc. Amer., 56, 275-370, 1945.

JGS - Japanese Geotechnical Society: Ground damage resulting from torrential rains in Fukui, July 2004, Emergency Survey Team, Soils and Foundations, 46, 869-884, 2006.

Hunter, G. and Fell, R.: The deformation behaviour of embankment dams, UNICIV Rep. N. R-416, School of Civil and Environmental Engineering, The University of New South Wales, 2003.

Kenney, T. C. and Lau, D.: Internal stability of granular filters, Can. Geotech. J., 22, 215-225, 1985.

Kenney, T. C. and Lau, D.: Internal stability of granular filters: reply, Can. Geotech. J., 23, 420-423, 1986.

Kezdi, A.: Soil Physics, Amsterdam, Elsevier, 1979.

Lane, E. W.: Security from under-seepage of masonry dams on earth foundations, Trans. ASCE, 60, 929-966, 1934.

Llasat, M. C., Barriendos, M., and Barrera, A.: The use of historical data in flood risk assessment - Application to Catalonia (NE Spain) 14th-20th centuries, in: View from the South, Environmental stories from the Mediterranean Word, edited by: Armiero, M., CNR - ISSM, Neaples, Italy, 95-111, 2006.

Miglietta, M. M. and Regano, A.: An observational and numerical study of a flash-flood event over south-eastern Italy, Nat. Hazards Earth Syst. Sci., 8, 1417-1430, doi:10.5194/nhess-8-1417-2008, 2008.

Morgenstern, N. R. and Price, V .E.: The analysis of the stability of general slip surfaces, Géotechnique, 15, 239-247, 1965.

Mossa, M.: The floods in Bari: What history should have taught, J. Hydraul. R., 45, 579-594, 2007.

Nash, J. E.: The form of instantaneous unit hydrograph, Int. Union of Geology and Geophysics, Assembly of Toronto, 3, 114-120, 1957.

Ortega, J. A. and Garzón, G.: A contribution to improved flood magnitude estimation in base of palaeoflood record and climatic implications - Guadiana River (Iberian Peninsula), Nat. Hazards Earth Syst. Sci., 9, 229-239, doi:10.5194/nhess-9-2292009, 2009.

Petrucci, O. and Polemio, M.: Hydrogeological multiple hazard: a characterisation based on the use of historical data, Landslides, edited by: Rybar, J., Stemberk, J., and Wagner, P., 269-274, 2002.

Petrucci, O. and Polemio, M.: Flood risk mitigation and anthropogenic modifications of a coastal plain in southern Italy: combined effects over the past 150 years, Nat. Hazards Earth Syst. Sci., 7, 361-373, doi:10.5194/nhess-7-361-2007, 2007.
Petrucci, O. and Polemio, M.: The role of meteorological and climatic conditions in the occurrence of damaging hydro-geologic events in Southern Italy, Nat. Hazards Earth Syst. Sci., 9, 105118, doi:10.5194/nhess-9-105-2009, 2009.

Polemio, M.: Le calamità idrogeologiche dell'inverno 1995-96 nel territorio tarantino, Int. Conf. "La prevenzione delle catastrofi idrogeologiche: il contributo della ricerca scientifica", CNR IRPI, Alba, Italy, 1996, 63-73, 1998.

Polemio, M.: Historical floods and a recent extreme rainfall event in the Murgia karstic environment (Southern Italy), Z. Geomorph., 54, Suppl. Issue 2, 195-219, 2010.

Polemio, M. and Sdao, F.: Landslide hazard and critical rainfall in Southern Italy, in: Proc. VII Int. Symp. on landslides, Norway, Balkema, Rotterdam, 847-852, 1996.

Rodriguez-Iturbe, I. and Valdes, J. B.: The geomorphologic structure of hydrologic response, Water Resour. Res., 15, 1409-1420, 1979.

Schmertmann, J. H.: The non-filter factor of safety against piping through sands, ASCE geotechnical special publication n. 111, Judgement and Innovation, edited by: Silva, F. and Kavazanjian, E., ASCE, Reston, 2000.

Schmocker-Fackel, P. and Naef, F.: Changes in flood frequencies in Switzerland since 1500, Hydrol. Earth Syst. Sci., 14, 1581-1594, doi:10.5194/hess-14-1581-2010, 2010.

Serre, D., Peyras, L., Tourment, R., and Diab, Y.: Levee performance assessment methods integrated in a GIS to support planning maintenance actions, J. Infrastruct. Sys., 14, 201-213, 2008.

Skempton, A. W. and Brogan, J. M.: Experiments on piping in sandy gravels, Géotechnique, 44, 449-460, 1994.

Strahler, A. N.: Hypsometrie (area-altitude) analysis of erosional topology, Bull. Geol. Soc. Amer., 63, 1117-1142, 1952.

Ten Brinke, W., Bannink, B., and Ligtvoet, W.: The evaluation of flood risk policy in the Netherlands, in Proc. Instn. Civil Engrs., Water Management, 161, 181-188, 2008.

Tatsuoka, F., Tateyama, M., Mohri, Y., and Matsushima, K.: Remedial treatment of soil structures using geosynthetic-reinforcing technology, Geotext. Geomembranes, 25, 204-220, 2007.

Terzaghi, K.: Soil mechanics, a new chapter in engineering science, J. Instn. Civ. Engrs., 12, 106-141, 1939.

USDA - United States Department of Agriculture: Urban hydrology for small watersheds, Technical Release, 55 (TR-55), Natural Resources Conservation Service, Conservation Engineering Division, 1986.

Van Genuchten, M. T.: A closed-form equation for predicting the hydraulic conductivity of unsaturated soils, Soil Sci. Am. J., 44, 892-898, 1980.

Wan, C. F. and Fell, R.: Investigation of rate of erosion of soils in embankment dams, J. Geotech. Geoenviron. Eng, ASCE, 130, 373-380, 2004.

Wan, C. F. and Fell, R.: Assessing the potential of internal instability and suffusion in embankment dams and their foundations, J. Geotech. Geoenviron. Eng, ASCE, 134, 401-407, 2008. 